\title{
What affects international migration of European science and engineering graduates?
}

Citation for published version (APA):

de Grip, A., Fouarge, D., \& Sauermann, J. (2010). What affects international migration of European science and engineering graduates? Economics of Innovation and New Technology, 19(5), 407-421. https://doi.org/10.1080/10438590903434828

Document status and date:

Published: 01/01/2010

DOI:

10.1080/10438590903434828

Document Version:

Publisher's PDF, also known as Version of record

Document license:

Taverne

Please check the document version of this publication:

- A submitted manuscript is the version of the article upon submission and before peer-review. There can be important differences between the submitted version and the official published version of record.

People interested in the research are advised to contact the author for the final version of the publication, or visit the DOI to the publisher's website.

- The final author version and the galley proof are versions of the publication after peer review.

- The final published version features the final layout of the paper including the volume, issue and page numbers.

Link to publication

\footnotetext{
General rights rights.

- You may freely distribute the URL identifying the publication in the public portal. please follow below link for the End User Agreement:

www.umlib.nl/taverne-license

Take down policy

If you believe that this document breaches copyright please contact us at:

repository@maastrichtuniversity.nl

providing details and we will investigate your claim.
}

Copyright and moral rights for the publications made accessible in the public portal are retained by the authors and/or other copyright owners and it is a condition of accessing publications that users recognise and abide by the legal requirements associated with these

- Users may download and print one copy of any publication from the public portal for the purpose of private study or research.

- You may not further distribute the material or use it for any profit-making activity or commercial gain

If the publication is distributed under the terms of Article $25 \mathrm{fa}$ of the Dutch Copyright Act, indicated by the "Taverne" license above, 


\section{Economics of Innovation and New Technology}

\section{What affects international migration of European science and engineering graduates?}

\section{Andries de Grip , Didier Fouarge \& Jan Sauermann}

To cite this article: Andries de Grip, Didier Fouarge \& Jan Sauermann (2010) What affects international migration of European science and engineering graduates?, Economics of Innovation and New Technology, 19:5, 407-421, DOI: $10.1080 / 10438590903434828$

To link to this article: https://doi.org/10.1080/10438590903434828

$$
\text { 册Published online: } 14 \text { Jul } 2010 .
$$

Submit your article to this journal

Џ Article views: 458

Q View related articles $\sqsubset$

4 Citing articles: 7 View citing articles 


\title{
What affects international migration of European science and engineering graduates?
}

\author{
Andries de Grip $^{\mathrm{a}, \mathrm{b}}$, Didier Fouarge ${ }^{\mathrm{a}}$ and Jan Sauermann ${ }^{\mathrm{a} *}$ \\ ${ }^{a}$ Research Centre for Education and the Labour Market (ROA), Maastricht University, Maastricht, \\ The Netherlands; ${ }^{b}$ Institute for the Study of Labor (IZA), Bonn, Germany
}

(Received 30 May 2008; final version received 15 September 2009)

\begin{abstract}
Using a data set of science and engineering graduates from 12 European countries, we analyse the determinants of labour migration after graduation. We find that not only wage gains are driving the migration decision, but also differences in labour market opportunities, past migration experience and international student exchange are strong predictors of future migration. Contrary to our expectations, job characteristics such as the utilisation of skills in the job and involvement in innovation hardly affect the migration decision. When analysing country choice, countries such as the USA, Canada and Australia appear to attract migrants due to their larger R\&D intensity. Moreover, graduates with higher grades are more likely to migrate to these countries.
\end{abstract}

Keywords: migration; university graduates; scientists and engineers

JEL Classification: F22; J61

\section{Introduction}

International labour migration has been on the rise over the past decades (OECD 2007). Firms are competing for high-skilled labour in the international labour market in their attempt to strengthen their competitive edge. Research has shown that a non-negligible part of economic growth in the USA is due to skilled labour migration (OECD 2000). This internationalisation is particularly significant for students. Around the world, 1.8 million students were studying abroad in the year 2000. This figure is expected to rise to more than 7 million in 2025 (King, Ruiz-Gelices, and Findlay 2004). Within the European Union (EU), the Erasmus and Socrates grants for student exchange have largely contributed to promoting cross-country mobility among students. Since its start, the Erasmus/Socrates student exchange programme has financed 1.5 million students. At the start of the academic year 1987-1988, some 3000 students took part in the Erasmus programme. In the academic year 2006-2007, this number has risen to more than 153,000 students. In that year, students in 'engineering and technology' had a share of almost $11 \%$ in the number of outgoing students. ${ }^{1}$

\footnotetext{
*Corresponding author. Email: j.sauermann@maastrichtuniversity.nl
} 
In the international competition for talents, scientists and engineers are particularly important because of their involvement in innovation, and in the development of new products and technologies (Freeman 2006). Graduates in science and engineering (S\&E) studies are also likely to be more mobile than graduates in other disciplines because the international transferability of their knowledge and skills is larger. In public policy, international migration of $\mathrm{S} \& \mathrm{E}$ is therefore often seen as a chance of recruiting the most talented and productive workers. However, it can also be a risk in terms of losing a country's talented workers.

Using a unique data set of a cohort of S\&E students who graduated from universities in 12 European countries at the end of the 1990s, this article investigates the determinants of labour migration in the early stage of the career. While economic studies on migration have focused on wages and other work-related determinants of migration (Harris and Todaro 1970), we extend this focus by analysing the effect of 'quantitative' labour market incentives such as wage, market size for S\&E workers or previous labour market experience and 'qualitative' labour market incentives such as utilisation of skills or involvement in research and development (R\&D). Furthermore, we study about the differences in the determinants for the choice of destination countries in a multinomial logit context: no migration, migration to other EU countries or migration to non-European Anglo-Saxon countries that traditionally attract many foreign S\&E students and workers (Borjas 2006). The analysis of country choice of young graduates has received little attention in the literature, probably due to lack of data. An exception is the study of Constant and D'Agosto (2010) who investigate the migration decision of Italian graduates and show that both push and pull factors determine the choice of the country to which to migrate. ${ }^{2}$

The remainder of this article is structured as follows. In Section 2, we discuss the theoretical framework based on the results from previous studies. In Section 3, we present our data and the empirical model. Results are discussed in Section 4. We conclude in Section 5.

\section{Determinants of migration}

\subsection{Quantitative and qualitative aspects}

There is a large body of theoretical and empirical literature on migration (Borjas 1994). Economic literature has emphasised the importance of career prospects in migration decisions. Therefore, the employment and wage opportunities in the host country and the expected future employment and wage prospects (Sjaastad 1962; Harris and Todaro 1970) are argued to be important determinants of the migration choice of individual workers. This means that the migration choice is driven by expectations about one's own labour market position in the destination country compared with the home country (Chiswick 1978). Moreover, migration appears to be highly selective: workers with better labour market perspectives and high levels of human capital are more likely to migrate (Cörvers, Heijke, and Lintjens 2007; Fratesi and Riggi 2007).

However, it is not likely that only potential wage gains determine the migration choices of S\&E graduates. Non-monetary drivers of migration are likely to play a role; research indeed suggests that graduates also value the qualitative aspects when making their migration decision such as reputation of the country of destination or intellectual achievement (Massey et al. 1993; Constant and D'Agosto, 2010). It is also likely that migrants aim at achieving a better job match. This is especially true for S\&E workers who have been shown to value wages relatively less (and non-pecuniary aspects of their job more) compared with workers with other qualifications (De Grip and Willems 2003; De Graaf, Heyma, and Van 
Klaveren 2007). It can therefore be argued that S\&E graduates will be more likely to migrate in order to achieve a better match between their skills and their job, such as better utilisation of skills and more involvement in innovation.

The S\&E graduate's choice whether or not to migrate is based on an ex ante evaluation of the relative costs and benefits of migration. This implies that an S\&E graduate $i$ will migrate from study country $j=k$ to host country $j=l$ if the expected utility of moving from $k$ to $l$, is higher than the expected utility from staying in $k$, net of migration costs. In this simple framework, the migration choice is based on a comparison of utility in the home and the host country $\left(V_{i k}(\cdot)\right.$ and $V_{i l}(\cdot)$, respectively), and migration costs $\left(C_{i k} \rightarrow l\right)$. The net benefits of migration for S\&E graduate $i\left(B_{i}\right)$ can be written as follows:

$$
B_{i}=V_{i l}\left(W_{i l}, Q_{i l}, M_{l}\right)-\left(V_{i k}\left(W_{i k}, Q_{i k}, M_{k}\right)-C_{i k \longrightarrow l}\right)
$$

where $W_{i j}$ represents the wage level, $Q_{i j}$, the qualitative aspects of the job match, country characteristics $M_{j}$ of country $j$ and costs of migration $C_{i k \rightarrow l}$. Country characteristics reflect the aspects such as business cycles, the market size for S\&E workers or a country's policy on R\&D investments.

The costs of migration may be related to the physical, cultural or linguistic distance (Belot and Ederveen 2005) and to the possible loss of social networks (Munton 1990). Previous migration experience such as stays abroad during studies is likely to play a role in graduates' cost-benefit evaluation whether or not to migrate (Liebig and Sousa-Poza 2004). Prior migration spells may facilitate migration choices since individuals have built up experience in living in foreign countries. Graduates with previous migration experience may also have better information on potential returns and costs of migration, for example, social costs related to migration (DaVanzo 1983).

According to King, Ruiz-Gelices, and Findlay (2004), participation in education in another country is positively correlated with past experience abroad. Schooling abroad has been found to influence future migration choices. Graduate students who have spent time abroad during their studies are more likely to report readiness to migrate to pursue their career (King and Ruiz-Gelices 2003). Parey and Waldinger (forthcoming 2010) also show that graduates who participated in an Erasmus/Socrates student exchange are indeed more mobile internationally after graduation. While migration during higher education can be expected to have a long-lasting impact on the future career and future migration, the motives for taking part in student exchange programmes are not always related to one's career: personal development, improving language skills and understanding another country's culture are also important motives (Olser 1998; King and Ruiz-Gelices 2003). Though labour market-related motives are less important in the eyes of students, previous migration experience may decrease the costs of future migration (e.g. by being able to speak foreign languages and to be acquainted with a foreign culture).

The net benefits of migration $B_{i}$ are not directly observable. However, the migration choice $m_{i k \rightarrow l}$ which is based on the evaluation of $B_{i}$ can be observed as follows:

$$
m_{i k \rightarrow l}= \begin{cases}1 & \text { if } B_{i}>0 \\ 0 & \text { otherwise }\end{cases}
$$

The model shows that the expected pay-off of migration depends on individual-and locationspecific characteristics. Individual $i$ will migrate if he or she expects a higher utility elsewhere, net of cost of relocation. Henceforth, the migration $m_{i k \rightarrow l}$ choice is a positive function of expected utility in the destination country, a negative function of expected utility in the home country and a negative function of migration costs. 


\section{Data and empirical models}

\subsection{Data}

For the analysis, we use data from the REFLEX project. REFLEX is a European-wide survey among graduates which was conducted between March 2005 and May 2006 among persons who graduated from European universities in the years 1999-2001. ${ }^{3}$ It contains information on the study in which a person graduated about 5 years ago, such as the study programme and the length of studies. Labour market-related information is available for the first job after graduation and the current job at the time of the survey (i.e. the job held 5 years after graduation).

The data contain detailed information on an individual's migration history: where the parents were born, where graduates themselves were born, where they lived at the age of 16 , in which country they mainly went to university and where they eventually graduated. There is also information on whether a person participated in a student exchange programme or worked abroad during studies. In addition, graduates were asked in which country they held their first job, and in which country they currently live and work.

Although migration is usually defined as living in a different country than the country of birth, we define migration as leaving the country of graduation for work purposes. ${ }^{4} \mathrm{We}$ use this definition for two reasons. First, it is more appropriate to study the transition from universities in a particular country to the labour market. Otherwise, we would include early childhood migration. Second, this definition is better suited for the issue of brain retention; from the perspective of a global competition for human capital, it is important to assess whether or not countries are able to retain the human capital in which they invest.

Throughout this study, we define scientists and engineers as graduates from S\&E studies. While other studies define scientists and engineers as persons engaged in R\&D or as those working in high-tech industries (OECD 2000), we use the educational definition because it is more precise and we are especially interested in analysing migration behaviour after graduating from university. More specifically, we focus on the graduates of science, mathematical or computer studies, and from engineering, manufacturing and construction studies. Graduates in other fields of study are excluded from the analyses. Regarding the level of higher education, the survey is restricted to graduates who are in International Standard Classification of Education (ISCED) 5A studies (i.e. bachelor, master or equivalent). ${ }^{5} \mathrm{We}$ also selected individuals only if they are in paid employment after graduation or 5 years after graduation. ${ }^{6}$

\subsection{Empirical models}

Two types of analyses are performed to study the migration choices of graduates from S\&E studies. First, we analyse the choice whether or not to migrate. Second, we analyse the choice of the destination country by differentiating the migration decision with respect to geographical areas.

\subsubsection{The decision to migrate}

We use logit models to analyse the determinants of two binary migration choices separately: (i) whether $\mathrm{S} \& \mathrm{E}$ graduates migrate to a different country than their graduation country for their first job and (ii) whether they migrate for the job 5 years after graduation. In both cases, the reference group consists of S\&E graduates who work in the graduation country. We analyse both decisions to migrate, since this allows us to investigate whether there are differences in the determinants of migration in the short term, compared with the medium 
term ( 5 years after graduation). In order to control for unobserved characteristics that could affect the individual's propensity to migrate, we take advantage of the quasi-panel structure of our data and use the migration status in the first and the current job as two distinct observations of the same event over time. Probably due to the lack of appropriate data, this is rarely done in the literature.

As discussed in Section 2.1, we analyse the effect of 'quantitative' and 'qualitative' aspects of jobs on migration. We use three different types of variables to cover 'quantitative' aspects: first, the wage level in a job; second, R\&D intensity in the host country and third, we use a set of dummy variables reflecting previous experience with migration. It is expected that migrants will achieve higher wage levels than they would have earned in their home country. ${ }^{7} \mathrm{R} \& \mathrm{D}$ intensity is measured as the public and private spending on R\&D relative to a country's gross domestic product. The data are taken from OECD (2006) and pertains to both public and private R\&D spending in the various OECD countries in the years of migration for the first and the current job (i.e. 2001 and 2005, respectively). A higher R\&D intensity indicates a larger labour market for $S \& E$ graduates who may be involved in R\&D, and should be positively correlated with migration. ${ }^{8}$

A graduate's migration experience is captured by dummy variables indicating whether or not the individual was living in the country of graduation at the age of 16 , whether or not the parents were born abroad and whether or not the individual spent some time abroad for study or work-related purposes during his or her S\&E study. Moreover, the migration status in the first job is controlled for in the regression for migration in the current job. Additional controls for (1) personal characteristics (such as age, gender), (2) studyrelated characteristics (details of study programme) and (3) job-related characteristics are also included in the models. See Table 1 for details on the variables used. The table also indicates whether or not the variables are time-varying.

The most important qualitative job aspects are the utilisation of skills in the job, and being involved in innovation. The degree of utilisation of one's skills is self-reported. It measures the extent to which S\&E graduates use their skills in their first, and their current job. ${ }^{9}$ A second qualitative job aspect, which might be relevant for S\&E graduates, is 'being involved in innovation', which is defined as being one if an individual is involved in the innovation of either products and services, knowledge and methods, or technology, tools and instruments. The information on involvement in innovation is available for the current job only. As argued previously, a better utilisation of skills and greater involvement in R\&D may be a reason why $S \& E$ workers choose to migrate. ${ }^{10}$

\subsubsection{Country choice}

In the second part of the analysis, we analyse the choice for the destination country when migrating. In a multinomial logit framework, the dependent variable is defined according to the country where the S\&E graduate moved to. It equals one if a graduate migrates to another country within the EU, and it equals two for graduates who migrate to the USA, Canada or Australia. The reference group consisted of non-migrants. ${ }^{11}$ In this country choice analysis, the two migration choices are pooled in order to have sufficient numbers of migrants by destination countries. The model uses the same covariates as the ones used in the previous model (Table 1).

In order to take 'selectivity in the migration decision' into account, we perform an additional analysis in which we apply a Heckman-type correction in the country choice equation (Heckman 1979). On the first stage, the probability to migrate in the first place is estimated. The main equation of country choice is augmented by a correction term. 
Table 1. Dependent and independent variables (first and current job).

\begin{tabular}{|c|c|c|}
\hline Variable name & Definition & Availability \\
\hline \multirow[t]{2}{*}{ Migration destination } & Migration for first (current) job (dummy) & First and current job \\
\hline & $\begin{array}{l}\text { Migration destination: } 0 \text { for non-migrants, } \\
1 \text { if a person moves within the EU and } 2 \text { if } \\
\text { a person moves to the USA, Canada, or } \\
\text { Australia }\end{array}$ & First and current job \\
\hline $\begin{array}{l}\text { Migration background of } \\
\text { the parents }\end{array}$ & $\begin{array}{l}\text { Mother or father not born in graduation country } \\
\text { (dummy) }\end{array}$ & Time constant \\
\hline $\begin{array}{l}\text { Migration experience at } \\
\text { the age of } 16\end{array}$ & $\begin{array}{l}\text { Graduation country, not country at the age of } \\
16 \text { (dummy) }\end{array}$ & Time constant \\
\hline Year abroad for studies & Student exchange (dummy) & Time constant \\
\hline Year abroad for work & Work stay abroad during studies (dummy) & Time constant \\
\hline Gender (male) & Gender (dummy; male $=1$ ) & Time constant \\
\hline Age & Age in years & First and current job \\
\hline Living with partner & $\begin{array}{l}\text { Partner in the last year of the studies (at the } \\
\text { time of the interview) (dummy) }\end{array}$ & First and current job \\
\hline Having a child & Having a child when starting to work (dummy) & First job only \\
\hline Log wage & $\begin{array}{l}\text { Logarithm of gross hourly earnings first } \\
\text { (current) job, PPP-adjusted }\end{array}$ & First and current job \\
\hline Temporary contract & $\begin{array}{l}\text { Fixed-term contract in the first (current) job } \\
\text { (dummy) }\end{array}$ & First and current job \\
\hline Number of employers & Number of employers since graduation & Current job only \\
\hline Utilisation of skills & $\begin{array}{l}\text { Extent to what knowledge and skills were } \\
\text { utilised in the first (current) job ( } 1-5 ; 1 \text { 'to a } \\
\text { very low extent', } 5 \text { 'to a very high extent') }\end{array}$ & First and current job \\
\hline Involved in innovation & Being involved in innovation (dummy) & Current job only \\
\hline R\&D intensity & $\begin{array}{l}\text { R\&D expenditures relative to GDP (computed } \\
\text { from OECD 2006) }\end{array}$ & First and current job \\
\hline Working in manufacturing & $\begin{array}{l}\text { Job in manufacturing sector (dummy; working } \\
\text { in manufacturing sector }=1 \text { ) }\end{array}$ & First and current job \\
\hline Working hours & Contract hours first (current) job & First and current job \\
\hline $\begin{array}{l}\text { Length of study } \\
\text { programme }\end{array}$ & Years of study in the programme & Time constant \\
\hline Part-time studies & Part-time study programme (dummy) & Time constant \\
\hline Relative grade & $\begin{array}{l}\text { Grade relative to other students ( } 1-5 ; 1 \text { 'much } \\
\text { lower than average', } 5 \text { 'much higher than } \\
\text { average') }\end{array}$ & Time constant \\
\hline Internships during studies & $\begin{array}{l}\text { Internships/work placements as part of study } \\
\text { programme (dummy) }\end{array}$ & Time constant \\
\hline $\begin{array}{l}\text { Work experience during } \\
\text { studies }\end{array}$ & Work experience during studies (dummy) & Time constant \\
\hline $\begin{array}{l}\text { Vocational oriented } \\
\text { studies }\end{array}$ & $\begin{array}{l}\text { Programme was vocationally orientated } \\
\text { (dummy) }\end{array}$ & Time constant \\
\hline Studies in science & $\begin{array}{l}\text { Fields of studies: math, stat, computing, } \\
\text { physics (dummy) }\end{array}$ & Time constant \\
\hline
\end{tabular}

\section{Empirical analysis}

\subsection{Descriptive statistics}

As illustrated in Panel A of Table 3, 3.1\% of all S\&E graduates report that their first job was in another country than the graduation country. ${ }^{12}$ The largest share of them report migration within the EU. For migration in the current job 5 years after graduation, the pattern is not very different (Panel B): $2.6 \%$ of the $\mathrm{S} \& \mathrm{E}$ graduates report that their current job is abroad. Again, the largest share of them migrated within the EU. Of all respondents, $4.6 \%$ were migrants in either the first or the current job (Panel C). 
Table 2. Descriptive statistics.

\begin{tabular}{|c|c|c|c|c|}
\hline & \multicolumn{2}{|c|}{ Migration for first job } & \multicolumn{2}{|c|}{ Migration for current job } \\
\hline & $=0$ & $=1$ & $=0$ & $=1$ \\
\hline Migration background of the parents & 0.08 & 0.26 & 0.09 & 0.27 \\
\hline Migration experience at the age of 16 & 0.01 & 0.13 & 0.01 & 0.16 \\
\hline Year abroad for studies & 0.20 & 0.51 & 0.17 & 0.36 \\
\hline Year abroad for work & 0.05 & 0.15 & 0.07 & 0.16 \\
\hline Gender (male) & 0.68 & 0.63 & 0.71 & 0.66 \\
\hline Age & 25.89 & 25.71 & 27.26 & 27.43 \\
\hline Living with partner & 0.22 & 0.10 & 0.61 & 0.60 \\
\hline Having a child & 0.04 & 0.04 & 0.03 & 0.04 \\
\hline Log wage & 2.24 & 2.23 & 2.58 & 2.69 \\
\hline Temporary contract & 0.52 & 0.61 & 0.18 & 0.38 \\
\hline Utilisation of skills & 3.55 & 3.67 & 3.85 & 4.04 \\
\hline $\mathrm{R} \& \mathrm{D}$ intensity & 1.96 & 2.17 & 2.02 & 2.04 \\
\hline Working in manufacturing & 0.33 & 0.25 & 0.38 & 0.34 \\
\hline Working hours & 38.34 & 39.79 & 38.41 & 38.87 \\
\hline Length of study programme & 4.26 & 4.38 & 4.32 & 4.48 \\
\hline Part-time studies & 0.12 & 0.05 & 0.14 & 0.07 \\
\hline Relative grade & 3.59 & 3.87 & 3.62 & 3.84 \\
\hline Internships during studies & 0.54 & 0.52 & 0.44 & 0.54 \\
\hline Work experience during studies & 0.43 & 0.53 & 0.44 & 0.53 \\
\hline Vocational oriented studies & 2.94 & 3.01 & 3.06 & 2.89 \\
\hline Studies in science & 0.29 & 0.26 & 0.25 & 0.35 \\
\hline Number of employers & - & - & 1.90 & 2.00 \\
\hline Involved in innovation & - & - & 0.71 & 0.78 \\
\hline Number of observations & \multicolumn{2}{|c|}{3609} & \multicolumn{2}{|c|}{5181} \\
\hline
\end{tabular}

Although the numbers seem to be quite low, they are in line with the findings of other studies. Docquier and Rapoport (2009) report a rate of overall migration of 3.3\% and 5.4\% for skilled workers from Western Europe. Using a large-scale EU survey, Vandenbrande et al. (2006) report rates of past migration for the age group 25-34 equal to 5\%. ${ }^{13}$

Despite the similar percentages, the migration patterns are not always the same. Following Faggian, McCann, and Sheppard (2007), Panel C distinguishes five different patterns of migration behaviour: migration from the country of graduation to another country for the first job, and again to another country for the current job (repeat migrants); migration from the country of graduation to another country for the first job and return to the country of graduation (return migrants); migration from graduation country to another country for the first job where one stays for subsequent jobs (permanent migrants); migration from the graduation country to another country 5 years after graduation (late migrants) and staying in the graduation country (stayers or non-migrants). As Table 3 illustrates, about $1 \%$ of the S\&E graduates migrated for the first job and stayed abroad for subsequent jobs. Only a very small group migrated from a foreign country to another foreign country between the first and the current job. About $1.7 \%$ returned to the graduation country within 5 years after graduation, and $1.7 \%$ were late migrants (Table 3 ).

\subsection{Logit analysis of migration behaviour}

Table 4 shows the results of the estimates of the binomial logit model on migration for the first job after graduation and for the current job, 5 years after graduation. The third column shows the results from the random effects logit estimation, using the panel data structure 
Table 3. Figures on migration patterns (\%).

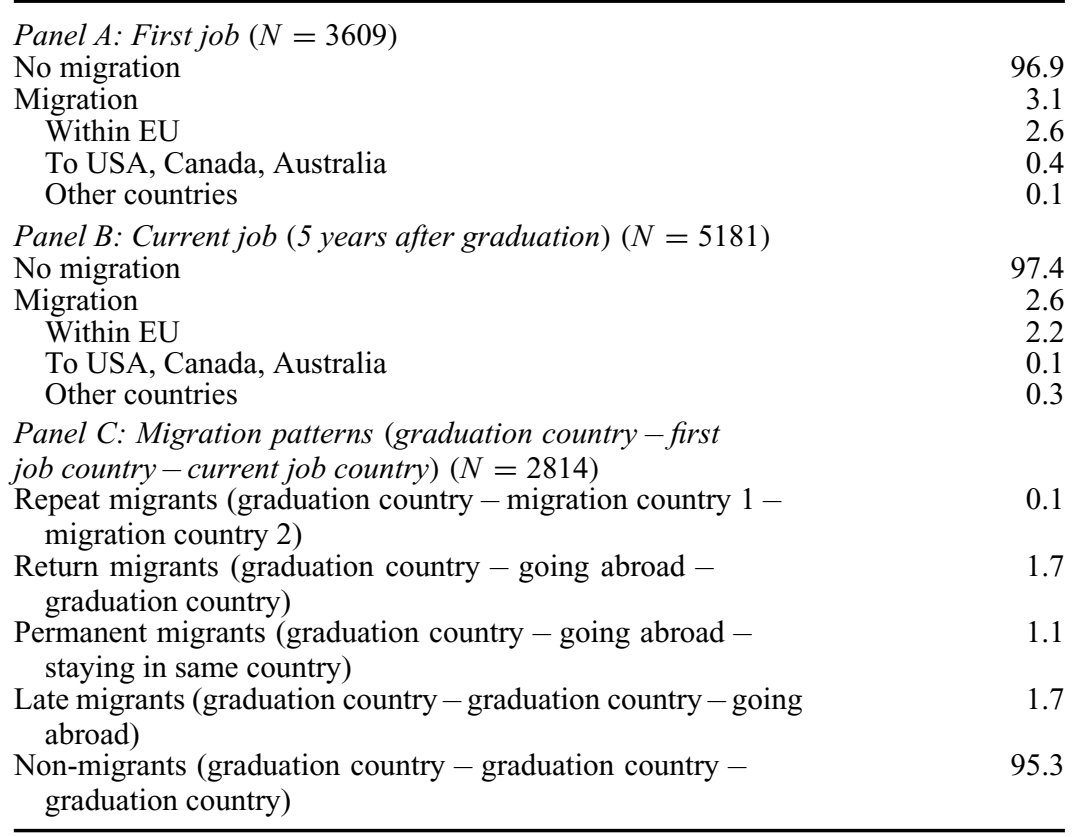

Notes: All figures are related to migration in either the first or the current job. Migration is defined as migration from the graduation country to the first or current job country. Unweighted data.

of our data. Concerning the quantitative incentives for migration, the model shows that a higher wage in the destination country has a large positive impact on migration choices for the current job. The fact that we also find a positive wage effect on the panel specification suggests that wage gains from migration are not due to individual characteristics - such as ability and motivation - that are unobserved in the data. While we find no wage premium for the migration in the first job, we do find a significant positive effect of R\&D intensity. This suggests that $S \& E$ graduates who migrate for the first job choose for countries with a large market for S\&E workers. They pick up the fruits of this choice in terms of a higher wage in the current job.

As discussed in Section 2, previous migration experience is a strong predictor of future migration choices. Table 4 shows that this is also true for $\mathrm{S} \& \mathrm{E}$ graduates. Graduates with migration experience at the age of 16 more often migrate to a different country after graduation. Moreover, graduates who had spent some time abroad during their studies for study or work purposes have a higher probability of going abroad after graduation. The migration background of the parents also has a significant positive effect on migration after graduation. Accordingly, migration to the first job after graduation is expected to determine the choice to stay abroad for subsequent jobs. This could be the case when some individuals are more open to migrate to other countries than others. The readiness to migrate to other countries may either be an innate skill, or based on the social background. The panel regression indeed suggests that at the individual level there is a large unobserved heterogeneity in the likelihood to migrate. This is indicated by the fact that the share of the error that can be attributed to unobserved differences across individuals is large (0.723) and significant. The inclusion of the variable 'migration for the first job' into the regression of 'migration 
Table 4. Logit estimates of choice to migrate.

\begin{tabular}{|c|c|c|c|}
\hline & Logit first job & Logit current job & Panel logit (RE) \\
\hline $\begin{array}{l}\text { Migration background of } \\
\text { the parents }\end{array}$ & $0.542 * *(0.276)$ & $0.568 * *(0.289)$ & $0.886 * *(0.384)$ \\
\hline $\begin{array}{l}\text { Migration experience at the } \\
\text { age of } 16\end{array}$ & $2.000 * * *(0.371)$ & $1.694 * * *(0.414)$ & $4.133 * * *(0.692)$ \\
\hline Migration (first job) & & $3.574 * * *(0.202)$ & \\
\hline Year abroad for studies & $1.069^{* * *}(0.210)$ & $0.293(0.202)$ & $1.379 * * *(0.280)$ \\
\hline Year abroad for work & $0.821 * * *(0.281)$ & $0.526 *(0.307)$ & $1.509 * * *(0.388)$ \\
\hline Gender (male) & $0.031(0.141)$ & $-0.205(0.232)$ & $-0.042(0.260)$ \\
\hline Age & $0.002(0.039)$ & $-0.026(0.031)$ & $-0.015(0.039)$ \\
\hline Living with partner & $-1.083 * * *(0.265)$ & $0.071(0.258)$ & $-0.490 * *(0.230)$ \\
\hline Having a child & $0.338(0.338)$ & & \\
\hline Log wage & $0.015(0.213)$ & $1.200 * *(0.500)$ & $1.012 * * *(0.292)$ \\
\hline Temporary contract & $0.462 * *(0.197)$ & $1.146 * * *(0.238)$ & $1.204 * * *(0.257)$ \\
\hline Utilisation of skills & $-0.090(0.090)$ & $0.054(0.111)$ & $-0.061(0.103)$ \\
\hline $\mathrm{R} \& \mathrm{D}$ intensity & $2.131 *(1.190)$ & $-0.097(0.220)$ & $1.285 * * *(0.322)$ \\
\hline Working in manufacturing & $-0.357(0.222)$ & $0.039(0.129)$ & $-0.255(0.253)$ \\
\hline Working hours & $0.024(0.018)$ & $0.071 * * *(0.014)$ & $0.063 * * *(0.018)$ \\
\hline Length of study programme & $0.105(0.129)$ & $0.240 *(0.134)$ & $0.320 *(0.176)$ \\
\hline Part-time studies & $-0.711 *(0.378)$ & $-0.423(0.362)$ & $-0.896 * *(0.424)$ \\
\hline Relative grade & $0.336 * * *(0.098)$ & $10.255^{* *}(0.127)$ & $0.441 * * *(0.158)$ \\
\hline Internships during studies & $-0.172(0.180)$ & $0.083(0.331)$ & $0.042(0.279)$ \\
\hline $\begin{array}{l}\text { Work experience during } \\
\text { studies }\end{array}$ & $0.259(0.195)$ & $0.197(0.300)$ & $0.293(0.268)$ \\
\hline Vocational oriented studies & $0.114(0.082)$ & $-0.056(0.066)$ & $0.034(0.111)$ \\
\hline Studies in science & $-0.244(0.206)$ & $0.408(0.258)$ & $0.131(0.270)$ \\
\hline Number of employers & & $-0.027(0.124)$ & \\
\hline Involved in innovation & & $-0.141(0.246)$ & \\
\hline Constant & $-9.788 * * *(2.181)$ & $-11.614 * * *(1.561)$ & $-20.055^{* * *}(2.541)$ \\
\hline$\rho$ & & & $0.723 * * *(0.055)$ \\
\hline Observations & 3609 & 5181 & 9235 \\
\hline Pseudo- $R^{2}$ & 0.227 & 0.349 & \\
\hline Log-likelihood & -386.0 & -407.2 & -916.8 \\
\hline$\chi^{2}$ & & & $97.450 * * *$ \\
\hline
\end{tabular}

Notes: Clustered standard errors are given in parentheses. Graduation country dummies are included. Dependent variable: 0 , no migration; 1 , migration.

$* p<0.10, * * p<0.05$ and $* * * p<0.01$.

for the current job' in any case shows that it is a strong predictor of the current migration status. $^{14}$

Although we expected that a better match between skills and job requirements would be a motive for migration for S\&E graduates, this is not supported by the data. There is no significant effect of utilisation of skills on the decision to migrate, neither in the first, nor in the current job. Moreover, the involvement in innovation in the current job is not a significant determinant for the choice of migration with respect to the current job. This suggests that a higher wage and better labour market opportunities are the main motives for migration.

Regarding the effect of human capital as reflected in the relative grade at graduation, the estimation results show that graduates with high grades in their studies more often migrate after graduation. ${ }^{15}$ This shows that the international competition for S\&E graduates is to some extent 'a war for talent' between countries. This effect remains significant in the panel estimation, suggesting that high grades are signalling high levels of ability to employers. A somewhat surprising result is that having a temporary contract is positively related to migration. This result might indicate that either employers tend to hire foreign workers rather 
as temporary workers (e.g. in order to screen them more intensively) or that graduates who migrate are more willing to accept temporary contracts. Moreover, graduates who migrate are more likely to work longer hours. This might indicate that certain graduates themselves opt to migrate.

The estimations do not reveal any significant differences in migration behaviour for graduates in sciences compared with engineering. Work experience or internship during the study also does not result in different migration behaviour between S\&E graduates. The age and the gender of graduates are not significantly related to migration. However, living together with a partner does have a negative effect on the probability to migrate for the first job.

In order to check for the robustness of the results, all analyses were also done for subsamples like young graduates, and those employed in particular sectors of industry. These results are not reported here, but coefficients and significance are not affected. Furthermore, the findings appear to be robust to our panel specification.

It is important to make a note on the interpretation of the results. First, although we include job-related variables in our models, we do not assume perfect foresight of individuals (i.e. they have perfect knowledge about future jobs). Second, we cannot identify the initial reason to go abroad: the choice to go abroad may not always be based on individual considerations, but may also be made in a broader social or family context (Massey et al. 1993). We do control for the family situation of an individual, but our data do not allow us to investigate whether or not the partner was involved in the migration choice or the country choice. Furthermore, other determinants of migration such as the availability of social networks or the distance of the migratory move could not be accounted for in the analysis.

\subsection{Analysis of country choice}

Table 5 shows the estimates of the multinomial logit model for the country choice of migrating $\mathrm{S} \& \mathrm{E}$ graduates. Taking graduates who do not migrate as the reference, we distinguish between migration to a country within the EU on the one hand and migration to the USA, Canada and Australia on the other hand. It is reasonable to assume that for the migration of EU graduates within the EU is easier because of the lack of legislative impediments. In these regressions, we pooled both migration choices for the first and the current job. ${ }^{16}$

The estimation results show that wages are an important driver of migration within the EU. However, wages do not play a significant role in the decision of S\&E graduates to migrate to the USA, Canada or Australia. Conversely, R\&D intensity is only significant for migration to these Anglo-Saxon countries. This suggests that migration to these three countries is particularly driven by better career prospects rather than immediate wage prospects (Sjaastad 1962).

As in the previous models, skills utilisation is not found to be significant in any of the equations. ${ }^{17}$ Remarkably, past migration experience of parents is significant for migration to another EU country but not for migration to the USA, Canada or Australia. Graduates with working and study experience abroad are less likely to remain in their country of graduation and migrate more often both to the other EU countries and the three Anglo-Saxon non-EU countries. Moreover, we find that S\&E graduates with a life science degree are more likely to migrate to the USA, Canada or Australia.

Positive self-selection due to the study grades relative to non-migrants is found for both destinations. The social costs of migration - which is proxied by the variable whether a graduate is living in a partnership or not - appear to be more important for migration to the 
Table 5. Pooled multinomial estimation of destination countries.

\begin{tabular}{|c|c|c|}
\hline & Migration within EU & $\begin{array}{l}\text { Migration to USA, } \\
\text { Canada and Australia }\end{array}$ \\
\hline Migration background of the parents & $0.620 * *(0.242)$ & $0.196(0.214)$ \\
\hline Migration experience at the age of 16 & $2.534 * * *(0.267)$ & $0.885^{* * *}(0.303)$ \\
\hline Year abroad for studies & $0.911 * * *(0.127)$ & $0.612 * * *(0.191)$ \\
\hline Year abroad for work & $0.699^{* * *}(0.186)$ & $1.690 * * *(0.226)$ \\
\hline Gender (male) & $-0.052(0.171)$ & $0.652 * *(0.269)$ \\
\hline Age & $0.011(0.014)$ & $-0.141 *(0.079)$ \\
\hline Living with partner & $-0.215(0.179)$ & $-1.007 * * *(0.128)$ \\
\hline Log wage & $0.854 *(0.441)$ & $-0.138(0.331)$ \\
\hline Temporary contract & $0.856^{* * *}(0.222)$ & $0.810^{* *}(0.316)$ \\
\hline Utilisation of skills & $-0.038(0.060)$ & $-0.085(0.098)$ \\
\hline R\&D intensity & $0.839(1.034)$ & $2.960 * * *(0.559)$ \\
\hline Working in manufacturing & $-0.135(0.140)$ & $-1.938 * * *(0.201)$ \\
\hline Working hours & $0.051 * * *(0.013)$ & $0.038^{* *}(0.018)$ \\
\hline Length of study programme & $0.222 *(0.117)$ & $0.318(0.264)$ \\
\hline Part-time studies & $-0.575 * *(0.266)$ & $-1.178 * * *(0.303)$ \\
\hline Relative grade & $0.295 * * *(0.096)$ & $0.543 * * *(0.134)$ \\
\hline Internships during studies & $0.022(0.250)$ & $0.142(0.309)$ \\
\hline Work experience during studies & $0.084(0.240)$ & $0.404 * * *(0.156)$ \\
\hline Vocational oriented studies & $0.002(0.043)$ & $0.063(0.175)$ \\
\hline Studies in science & $-0.122(0.191)$ & $0.917 * * *(0.234)$ \\
\hline Constant & $-11.663 * * *(1.850)$ & $-12.973 * * *(4.288)$ \\
\hline Observations & \multicolumn{2}{|c|}{9226} \\
\hline Pseudo- $R^{2}$ & \multicolumn{2}{|c|}{0.209} \\
\hline Log-likelihood & \multicolumn{2}{|c|}{-973.7} \\
\hline
\end{tabular}

Notes: Clustered standard errors are given in parentheses. Dependent variable: 0, no migration (reference); 1, migration within EU; 2, migration to USA, Canada or Australia.

${ }^{*} p<0.10,{ }^{* *} p<0.05$ and $* * * p<0.01$.

USA, Canada or Australia. This could be due to the longer distance between the graduation country and the host country. Moreover, while gender does not seem to play a role in the decision whether or not to migrate, males are more likely to migrate to USA, Canada or Australia. Older graduates are less likely to do so.

Because self-selection is likely to play a role in the choice of the country to which S\&E graduates migrate (Dostie and Léger 2009), we also estimated a Heckman selection model in order to check for the robustness of our findings with respect to the choice of the destination country when controlling for selection. The main equation estimates the probability of migrating to the USA, Canada or Australia versus migrating to another EU country as the reference category. The country choice equation contains a Heckman correction term in order to take selection effects into account. The results are reported in Table 6 (columns 1 and 2). For comparison, the table also reports the results from the country choice equation without correction for self-selection (column 3).

Despite the fact that self-selection is found to be significant, most results are in line with the estimation results from the multinomial logit model. Young S\&E graduates with a partner who have chosen to migrate are less likely to go to the USA, Canada or Australia than to migrate to another EU country. Male graduates, on the contrary, are more likely to migrate to the USA, Canada or Australia. A country's R\&D intensity affects the choice for the USA, Canada and Australia as destination countries in a positive way. So does a degree in science. Contrary to the multinomial logit result, the wage is not significant for the choice between the EU versus the USA, Canada and Australia. Similar to the results of the multinomial logit model, we also find that graduates with higher relative grades are more 
Table 6. Pooled two-step Heckman estimation of destination countries (probit specification).

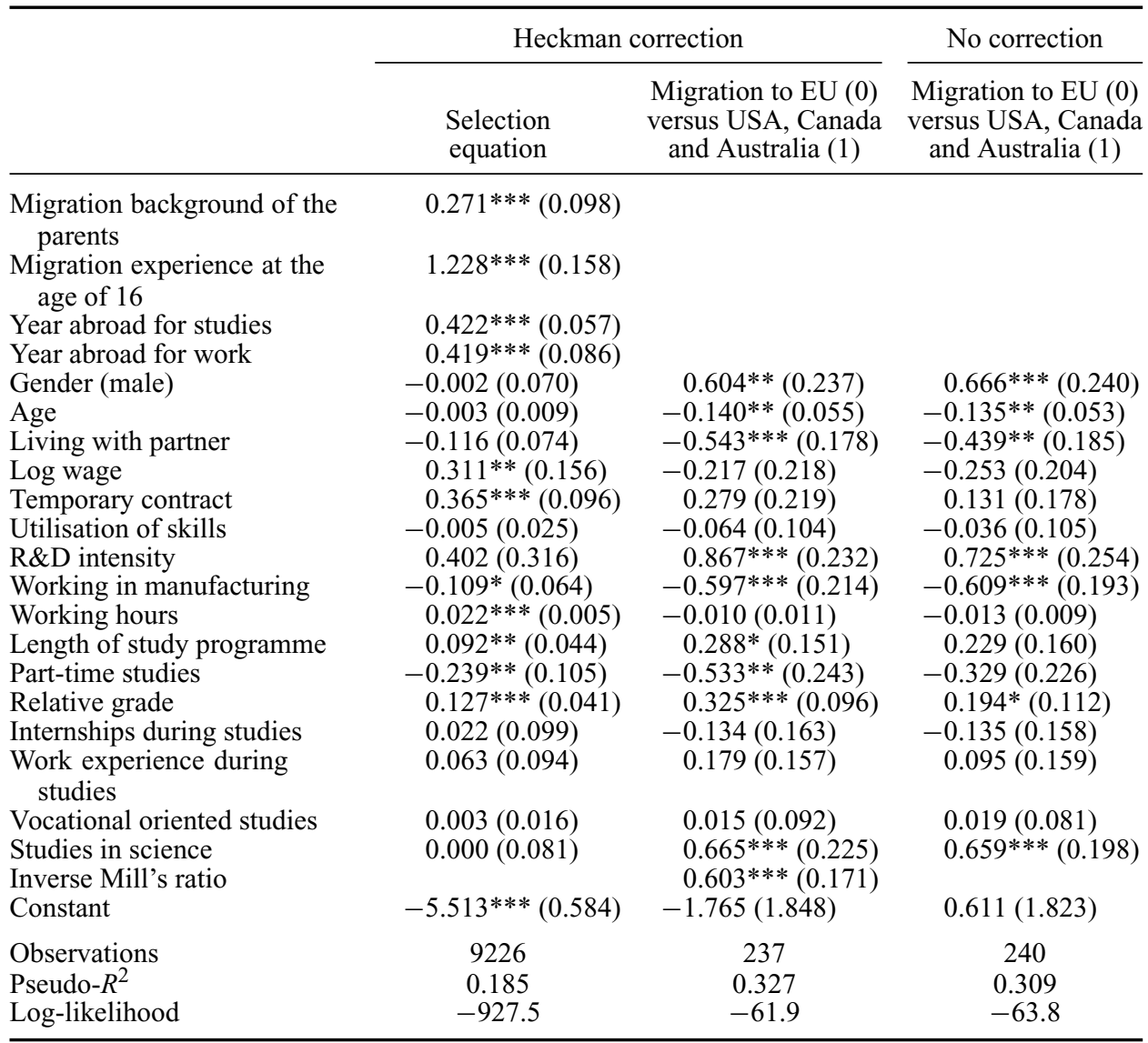

Notes: Clustered standard errors are given in parentheses. Graduation country dummies are included.

${ }^{*} p<0.10,{ }^{* *} p<0.05$ and ${ }^{* * *} p<0.01$.

likely to migrate to the USA, Canada and Australia. This result is in line with the findings of Grogger and Hanson (2008) who show that migrants select themselves into countries with higher returns to (their) skills.

The third column shows that this effect is underestimated (both in size and significance) if we do not control for selection. This means that it is not only that migrants have on average better grades than non-migrants, but also that the best of them choose to migrate to the USA, Canada or Australia, rather than migrating within the EU.

\section{Conclusion and implications}

In this article, we analyse the determinants of migration decisions of S\&E graduates from 12 European countries. The migration decisions directly after graduation as well as 5 years after graduation are studied using logit models. Taking advantage of the fact that we have two measurements of the migration status for each individual, we also applied panel methods. This allows us to control for unobserved individual differences in preference for migration. Furthermore, we analysed the country choice of migrating graduates, distinguishing between migration within the EU and migration to the USA, Canada or Australia. 
We find that the wage level and the intensity of R\&D in the destination country are more important for S\&E graduates' migration than qualitative aspects of jobs like the utilisation of skills and involvement in innovation. In their first job, migrants choose countries with an intensive R\&D sector, possibly because they seek better labour market prospects for themselves, which result in a higher wage in the current job.

We also find that previous migration experience of parents and migration during adolescence are strong predictors of migration to other EU countries, but not for migration to the USA, Canada or Australia. Moreover, international student exchange and time spent abroad for work or internships increase international mobility after graduation, although the former only holds for migration to another EU country. This implies that student exchanges, such as the EU-supported Socrates/Erasmus programmes, are a good way to stimulate the international mobility of S\&E graduates. Although this is probably partly due to a process of self-selection, it also shows that a country can recruit more foreign S\&Es by offering attractive studies and internships for foreign exchange students.

Obviously, international migration indicates a 'war for talent' as S\&E graduates with higher grades are more likely to migrate. Countries will particularly face a 'brain drain' of S\&E graduates if wages are low or labour market prospects - as indicated by a country's R\&D intensity - are poor, compared with other countries which may attract these graduates. Finally, our results show that migration to the first job after graduation is highly correlated with a job abroad 5 years later. This suggests that the international 'war for talent' focuses on S\&E students who have just graduated.

\section{Acknowledgements}

The authors would like to thank Jim Allen, Frank Cörvers and the participants at the workshop on the Labour Market for Scientists and Engineers at the Research Centre for Education and the Labour Market (ROA), and two anonymous referees for helpful comments.

\section{Notes}

1. See http://ec.europa.eu/education/programmes/llp/erasmus/statisti/table207.pdf

2. They show that the lack of funds for research is an important push factor for migration to the USA, that work experience abroad is a pull factor for migration to continental Europe, and that holding a $\mathrm{PhD}$ from outside Italy is a pull factor for migration to the UK.

3. For more information on the REFLEX project, see Allen and van der Velden (2008). The survey was conducted in Austria, Belgium, Czech Republic, Finland, France, Germany, Italy, the Netherlands, Norway, Spain, Switzerland and the UK. Due to missing variables, Estonia is excluded in the regression analysis. For some countries, a two-stage sampling process was applied: universities were drawn in the first stage and graduates from these universities in the second stage. When central registers of graduates were available, graduates were selected by a one-stage sampling process directly from the records. For all countries, the final sample was checked against the population. Only small deviations of the sample means from the population means could be detected.

4. When using the standard definition of migration, the number of migrants is higher than the $3.1 \%$ reported in Table 3: 5.6\% of all graduates in our sample start their first job in a country different from their country of birth.

5. Persons who graduated in doctoral studies are excluded; master graduates who start their doctoral studies are included in the sample though.

6. Internships and jobs shorter than 6 months are not included in the analysis.

7. Wages are corrected for differences in purchasing power across countries.

8. Because $R \& D$ intensity is clustered within destination countries, the standard errors are corrected accordingly.

9. The question on utilisation of skills is 'To what extent were your knowledge and skills utilised in this work?' The variable is measured on a five-point Likert scale. 
10. Descriptive statistics of the data used are shown in Table 2 .

11. A negligible fraction of graduates who migrate to other countries than the EU, USA, Canada or Australia are omitted from the analysis.

12. From this group, less than $9 \%$ are graduates who return to their country of birth.

13. A slight under-representation of migrants in the REFLEX data may also be due to the sampling method used: graduates going abroad may be less likely to respond or are less likely to be identified by their university.

14. Alternatively, we could model the bivariate migration choice for the first and the current job. The added value of this approach is, however, small because both choices are strongly correlated and not all covariates of interest are available for both jobs.

15. The measure of relative grades which is used in this study is based on a self-assessment.

16. We corrected the standard errors of the estimates to account for the fact that we have repeated measurements of the same individuals.

17. Involvement in innovation is not included in this model as it is only defined for the current job.

\section{References}

Allen, J., and R. van der Velden. 2008. The flexible professional in the knowledge society: General results of the REFLEX-project. Maastricht: Research Centre for Education and the Labour Market (ROA).

Belot, M., and S. Ederveen. 2005. Cultural and institutional barriers in migration between OECD countries. Working Paper, CPB Netherlands Bureau for Economic Policy, The Hague.

Borjas, G. 1994. The economics of immigration. Journal of Economic Literature 32: 1667-717.

Borjas, G. 2006. Native internal migration and the labor market impact of immigration. Journal of Human Resources 41: 221-58.

Chiswick, B. 1978. The effect of Americanization on the earnings of foreign-born men. Journal of Political Economy 86: 897-921.

Constant, A.F., and E. D'Agosto. 2010. Where do the brainy Italians go? In The labour market impact of the EU enlargement. A new regional geography of Europe?, ed. F. Caroleo and F. Pastore, 247-71. Berlin Heidelberg: Springer.

Cörvers, F., H. Heijke, and E. Lintjens. 2007. What do highly able graduates from the Netherlands decide after their studies: Going abroad, starting a PhD, or both? Discussion paper, Research Centre for Education and the Labour Market (ROA), Maastricht.

DaVanzo, J. 1983. Repeat migration in the United States: Who moves back and who moves on? Review of Economics and Statistics 65: 552-9.

De Graaf, D., A. Heyma, and C. Van Klaveren. 2007. De arbeidsmarkt van hoger opgeleide bèta's. Amsterdam: SEO Economisch Onderzoek.

De Grip, A., and E. Willems. 2003. Youngsters and technology. Research Policy 32: 1771-81.

Docquier, F., and H. Rapoport. 2009. Skilled migration: The perspective of developing countries. In Skilled migration: Prospects, problems and policy, ed. J. Bhagwati and G. Hanson, chapter 9. New York: Oxford University Press.

Dostie, B., and P.T. Léger. 2009. Self-selection in migration and returns to unobservable skills. Journal of Population Economics 22: 1005-24.

Faggian, A., P. McCann, and S. Sheppard. 2007. Some evidence that women are more mobile than men: Gender differences in U.K. graduate migration behavior. Journal of Regional Science 47: 517-39.

Fratesi, U., and M.R. Riggi. 2007. Does migration reduce regional disparities? The role of skillselective flows. Review of Urban and Regional Development Studies 19: 78-102.

Freeman, R. 2006. Does globalization of the scientific/engineering workforce threaten US economic leadership? In Innovation policy and the economy, vol. 6, ed. A.B. Jaffe, J. Lerner, and S. Stern, 123-58. Cambridge: MIT Press.

Grogger, J., and G.H. Hanson. 2008. Income maximization and the selection and sorting of international migrants. NBER Working Paper 13821, National Bureau of Economic Research (NBER), Washington, DC.

Harris, J.R., and M.P. Todaro. 1970. Migration, unemployment and development: A two-sector analysis. American Economic Review 60: 126-42.

Heckman, J.J. 1979. Sample selection bias as a specification error. Econometrica 47: 153-61. 
King, R., and E. Ruiz-Gelices. 2003. International student migration and the European year abroad: Effects on European identity and subsequent migration behaviour. International Journal of Population Geography 9: 229-52.

King, R., E. Ruiz-Gelices, and A. Findlay. 2004. International student mobility study. Study 2: Exploring the diversity of UK international student mobility. Brighton: Sussex Centre for Migration Research.

Liebig, T., and A. Sousa-Poza. 2004. Migration, self-selection and income inequality: An international analysis. Kyklos 57: 125-46.

Massey, D., J. Arango, G. Hugo, A. Kouaouci, A. Pellegrino, and J. Taylor. 1993. Theories of international migration: A review and appraisal. Population and Development Review 19: 431-66.

Munton, A. 1990. Job relocation, stress and the family. Journal of Organizational Behavior 11: 401-6.

OECD. 2000. Mobilising human resources for innovation. Paris: OECD.

OECD. 2006. OECD science, technology, and industry outlook. Paris: OECD.

OECD. 2007. International migration outlook. Paris: OECD.

Olser, A. 1998. European citizenship and study abroad: Student teachers' experiences and identities. Cambridge Journal of Education 28: 77-96.

Parey, M., and F. Waldinger. Forthcoming 2010. Studying abroad and the effect on international labor market mobility: Evidence from the introduction of ERASMUS. The Economic Journal.

Sjaastad, L.A. 1962. The costs and returns of human migration. Journal of Political Economy 70: $80-93$.

Vandenbrande, T., L. Coppin, P. van der Hallen, P. Ester, D. Fouarge, A. Fasang, S. Geerdes, and K. Schömann. 2006. Mobility in Europe. Dublin: European Foundation. 